\title{
A True's Beaked whale (Mesoplodon mirus) on the COAST OF BraZil: ADDING A NEW BEAKED WHALE SPECIES to the Western Tropical Atlantic and South America
}

\author{
Shirley P. de Souza ${ }^{1}$, Salvatore Siciliano ${ }^{2}$, Sandra Cuenca ${ }^{3}$, Bianca de Sanctis ${ }^{4}$
}

\begin{abstract}
A male True's Beaked Whale (Mesoplodon mirus) stranded alive on 04 May 2004, on the northern coast of São Paulo State, southeastern Brazil, and died twenty minutes later. To date, this species has only been recorded from the North Atlantic, southeast Africa and southern Australia. The complete skeleton was saved and the heart, stomach, testis, epizoites, samples of tissues, and blood were collected. This is the first record of M. mirus for the Western Tropical Atlantic (south of the Equator) and for South America. The record provides important information on this poorly known species.
\end{abstract}

Resumen: Un varamiento de un macho vivo de Zifio de True (Mesoplodon mirus) ha ocurrido en la costa norte de la Provincia de São Paulo, en el 4 de Mayo de 2004. El animal se ha muerto veinte minutos después de varado. Esta especie ha sido registrada solamente en el Atlántico Norte, sureste de África, y sur de Australia. El esqueleto completo ha sido colectado así como el corazón, estómago, testículos, epizoicos, muestras de tejidos y sangre. Este registro es el primer de M. mirus para el Atlántico Sur-Occidental y para la América del Sur, aportándonos importantes informaciones para esta especie poco conocida.

Keywords: Mesoplodon mirus, True's beaked whale, stranding, distribution

\section{Introduction}

Beaked whales of the genus Mesoplodon are the least known group among cetaceans. Their distribution, biology, behavior and external morphology are not fully described and the few data about them primarily come from analysis of skeletons and carcasses of stranded animals (Dalebout et al., 1998). Only 11 published records of stranded Mesoplodon are known for Brazil: Four M. grayi, three M. densirostris, two M. europaeus, one $M$. layardii, one $M$. cf. layardii and one $M$. hectori (Siciliano, 1994; Secchi and Zarzur, 1999; Pinedo et al., 2001; Zerbini and Secchi, 2001; Santos et al., 2003; Martins et al., 2004; Maia-Nogueira and Nunes, this issue).

True's beaked whale, Mesoplodon mirus, is among the least recorded species of Mesoplodon. The majority of records are in the Northwest Atlantic and less frequently in Ireland, France and Canary Islands, suggesting a probable relation with the Gulf Stream system (Mead, 1989; MacLeod, 2000). In the Southern Hemisphere they have been recorded in southeastern Africa and southern Australia. It is not clear whether populations of different hemispheres are geographically separated, or if the species distribution is wider than indicated by the known records (Ross, 1984).

\section{Material and Methods}

On 04 May 2004 a True's beaked whale stranded alive in São Sebastião $\left(23^{\circ} 46^{\prime} S-45^{\circ} 40^{\prime} W\right)$, northern coast of São Paulo state, southeastern Brazil (Figure 1). According to local people, the animal died after 20 minutes of unsuccessful attempts to return it to sea. Soon after death, the animal was photographed and morphological measurements were taken following the procedures of Norris (1961) and Perrin (1975) (Table 1). Swabs from the various orifices were collected as well. Tissue samples of muscle, blubber, skin, heart, lung, liver, kidney, pancreas, spleen (including accessory spleens), bladder, prostate, testes and intestine were also taken for histopathological, microbiological and contaminants analysis. Stomach contents, external and internal parasites, feces, blood and the complete skeleton were also collected. The mandibles, in which there were no teeth or alveoli, were cleaned by maceration, with care being taken to avoid the loss of any fragment which could aid in species identification. The skull and skeleton were recovered after three weeks and 10 months, respectively. The complete skeleton has been deposited at Instituto Terra $\mathcal{E}$ Mar under catalogue number SOSMM 130. The skull and mandibles were measured with calipers to the nearest $0.1 \mathrm{~mm}$ following procedures of Moore (1963) and Ross (1984).

\section{Results and Discussion}

The specimen was identified as a True's beaked whale (Mesoplodon mirus) based on the presence of the following characteristics: Tooth crypts (i.e. internal chambers corresponding to future alveoli) positioned in the tip of both hemi-mandibles (observed by X-ray, Figure 2), skull and mandible morphology (Figures 3 and 4), and diagnostic external coloration described for the species in the Southern Hemisphere (Baker, 1983).

\footnotetext{
${ }^{1}$ SOS Mamíferos Marinhos - Instituto Terra \& Mar - Rua Gertrudes Correa, 123, São Sebastião, SP 11600-000 Brazil. E-mail: shirley@terraemar.org.

${ }^{2}$ Grupo de Estudos de Mamíferos Marinhos da Região dos Lagos (GEMM-Lagos), Laboratório de Ecologia, Departamento de Endemias Samuel Pessoa, Escola Nacional de Saúde Pública/FIOCRUZ, Rua Leopoldo Bulhões, 1480-térreo, Manguinhos, Rio de Janeiro, RJ 21041-210 Brazil. E-mail: sal@ensp.fiocruz.br.

${ }^{3}$ UNIMONTE - Centro Universitário Monte Serrat, Avenida Rangel Pestana 99, Santos, SP 11013-551 Brazil. E-mail: scuenca@uol.com.br

${ }^{4}$ Rua Ministro Godoy, 1336/34, Perdizes, São Paulo, SP 05015-001 Brazil. E-mail: bisanctis@hotmail.com
} 


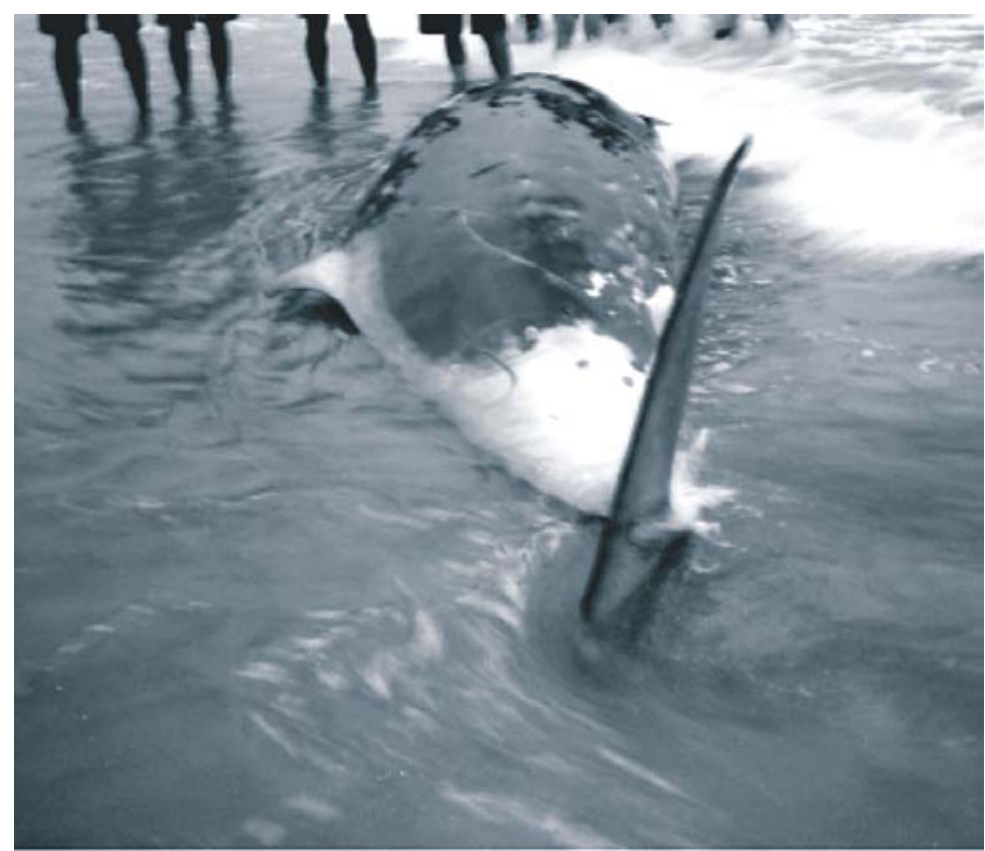

Figure 1. M. mirus, minutes after death

Table 1. Morphological measurements of a Mesoplodon mirus specimen, stranded in São Sebastião, São Paulo, Brazil in May 2004.

\begin{tabular}{lc}
\hline \hline MORPHOLOGICAL MEASUREMENTS DESCRIPTION & $\mathrm{cm}$ \\
\hline \hline 1. Length, total (tip of upper jaw to deepest part of notch between flukes & 460 \\
2. Length, tip of upper jaw to center of eye & 58 \\
3. Length, tip of upper jaw to apex of melon (snout length) & 14 \\
4. Length of gape (tip of upper jaw to angle of gape) & 37 \\
5. Length, tip of upper jaw to external auditory meatus & 68 \\
6. Center of eye to external auditory meatus (direct) & 12 \\
7. Center of eye to angle of gape (direct) & 20 \\
8. Center of eye to center of blowhole (direct) & 20 \\
9. Length, tip of upper jaw to blowhole along midline & 55 \\
10. Length, tip of upper jaw to anterior insertion of flipper & 93 \\
11. Length, tip of upper jaw to tip of dorsal fin & 306 \\
12. Length, tip of upper jaw to midpoint of umbilicus & 204 \\
13. Lenght, tip of upper jaw to midpoint of genital aperture & 297 \\
14. Length, tip of upper jaw to center of anus & 328 \\
15. Girth, on a transverse plane intersecting axilla & 212 \\
16. Girth, on a transverse plane intersecting the anus & 150 \\
17. Length, flipper (anterior insertion to tip) & 45 \\
18. Length, flipper (axilla to tip) & 417 \\
19. Width, flipper (maximum) & 36 \\
20. Height, dorsal fin (fin tip to base) & 15 \\
21. Width, flukes (tip to tip) & 17 \\
22. Distance from nearest point on anterior border of flukes to notch & \\
\hline \hline
\end{tabular}




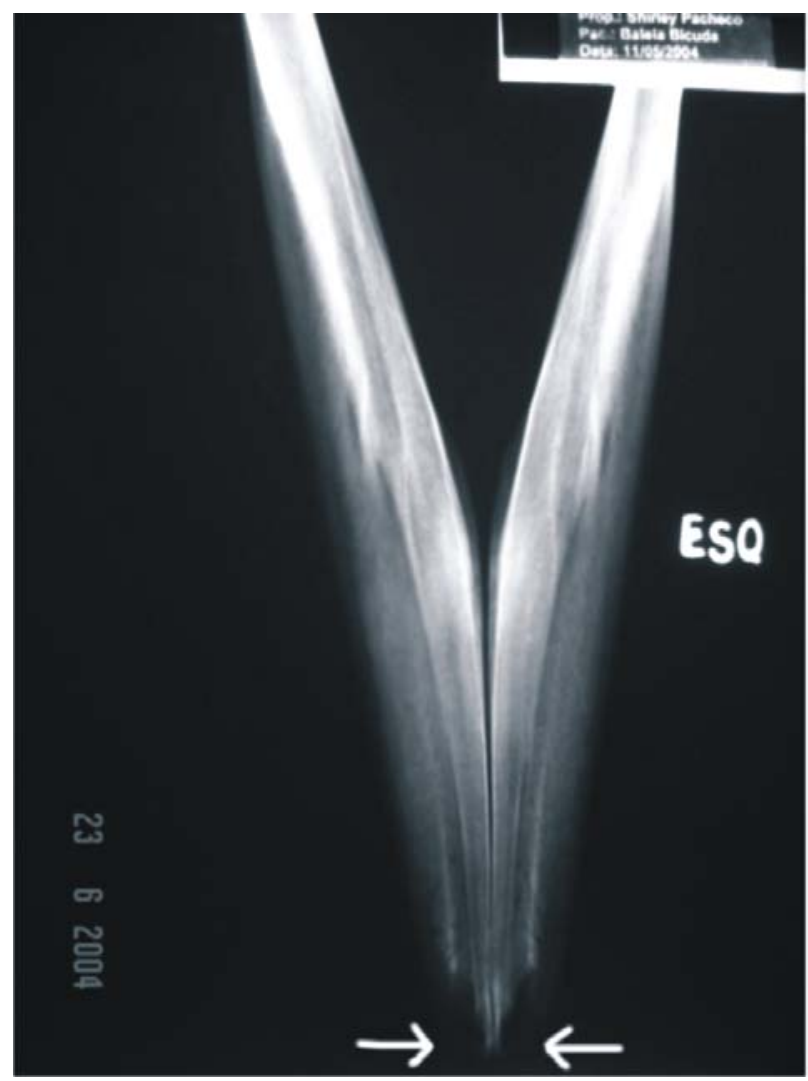

Figure 2. Position of the teeth's crypts

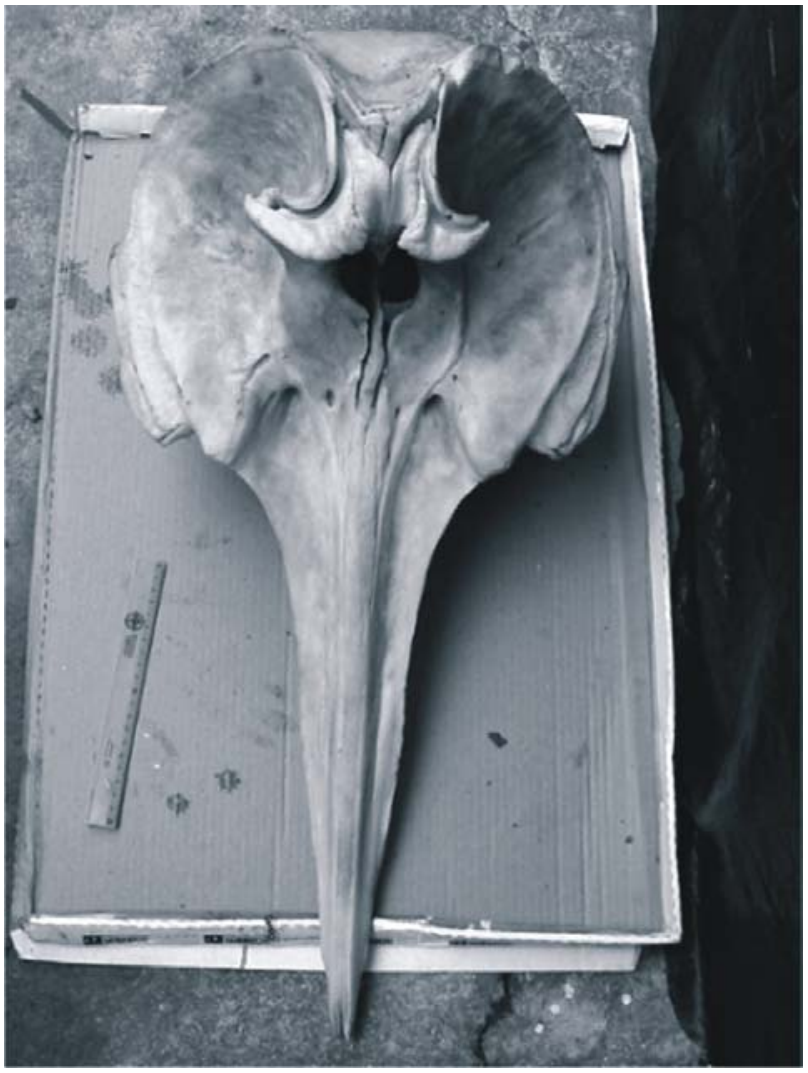

Figure 3. Skull of the M. mirus specimen

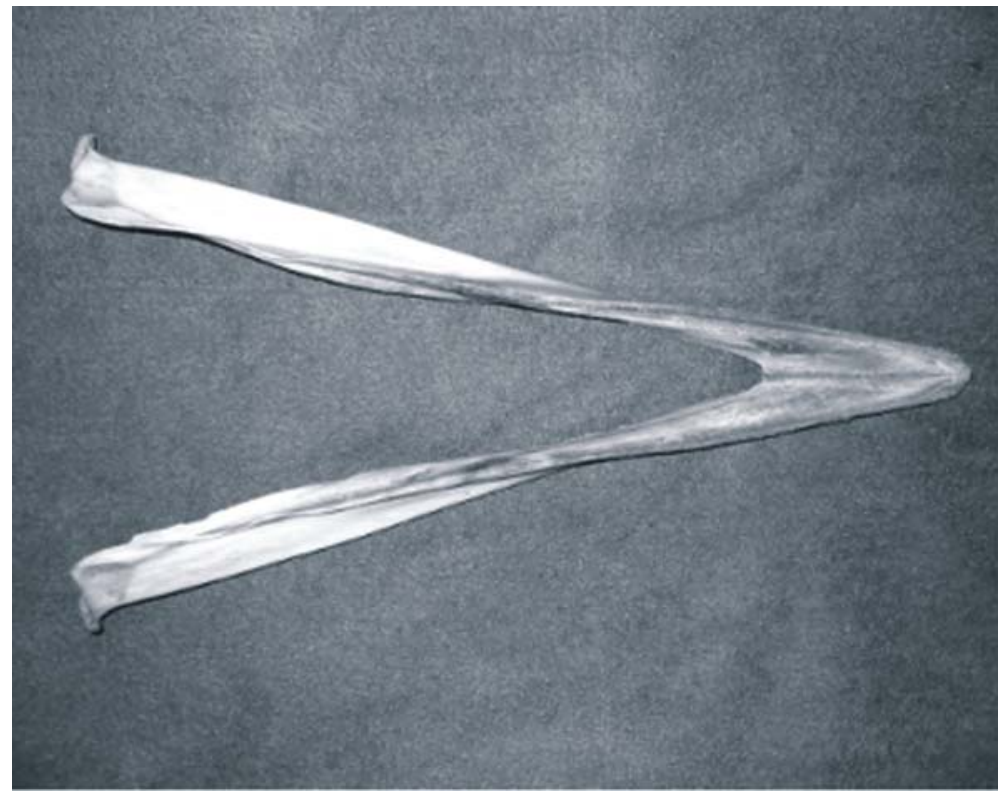

Figure 4. Mandibles of the M. mirus specimen 
The individual was a $460 \mathrm{~cm}$ long male, with gray coloration on its anterior dorsal body, and a white area from the anterior insertion of the dorsal fin to the insertion of the flukes, as previously described for Southern Hemisphere specimens by Mead (1989). There was a dark circular area around each eye and a light gray ventral area from the chin to the line between the flippers (see Figure 1). A white eliptical patch connecting the anal and genital slit was also present. Below each flipper there was an area of lighter pigmentation corresponding exactly to the flipper's contour. We noted that in this particular specimen, the conspicuous coloration of the fresh carcass agreed with the known coloration for the Southern Hemisphere specimens of M. mirus (Figure 1).

The dorsal fin was small, with a slightly concave posterior border and situated on the posterior third of the body. There was no central fluke notch. Several wounds and scars were present on the flanks and dorsal region, very similar to those caused by the cookie-cutter shark, Isistius sp. (Figure 5).

The condylobasal length of the skull was $75 \mathrm{~cm}$ and the vertebral formula was C7 + T10 + L11 + Ca $20=48$, which fits within the range for Mesoplodon cited by Mead (1989): C7 + T 9-11 + L 8-11 + Ca 17-21. Cranial measurements were taken following Moore (1963) and Ross (1984) and are shown in Tables 2 and 3.

The skull showed a very developed vertex (Figure 3) and the mesorostral channel was ossified. After maceration the mandible revealed an opened symphysis and an absence of teeth or alveoli (Figure 4). By examining the mandible through X-ray plates it was possible to determine "crypts of the teeth" in the tip of both hemi-mandibles. A total of 10 pairs of ribs, 4 sternebrae, 2 scapulas, 2 humerus, 2 radius, 2 ulnas, 24 bones from both manus, the complete hyoid apparatus and 11 chevrons were recovered. All the vertebra epiphyses were fused to their centra, as were all the epiphyses from the forelimb bones, the ventral hyoids and 9 of the 11 chevrons. This indicates that this male was physically mature. The last four right ribs presented marks of calcified fractures. The lack of any alveoli or teeth suggests that this was an anomalous specimen. Despite its physical and close-to sexual maturity, teeth did not develop during the course of its life, which is unusual for a male mesoplodont (Mead, 1989).

The main (fundic) stomach was $38 \mathrm{~cm}$ long in its greatest length and $15 \mathrm{~cm}$ wide in its greatest width, and the pyloric stomach was composed of four smaller interconnected sac-like structures. The stomach contained no food items, but pieces of plastic were present (Figure 6). There was a slight infection $(n=5)$ of Anisakis sp. parasites in the last chamber of the stomach. These parasites could not be classified to the species level due to the fact that all specimens were female (Dr. Luís C. Muniz-Pereira ${ }^{5}$, pers. commn, 2005). Previously, plastic debris has been found in other stranded beaked whales (e.g. in three beaked whales stomachs in the North Atlantic - Santos et al., 2001, and in a M. densirostris specimen from southern Brazil - Secchi and Zarzur, 1999), indicating a potential problem with marine debris on this particular group of whales.

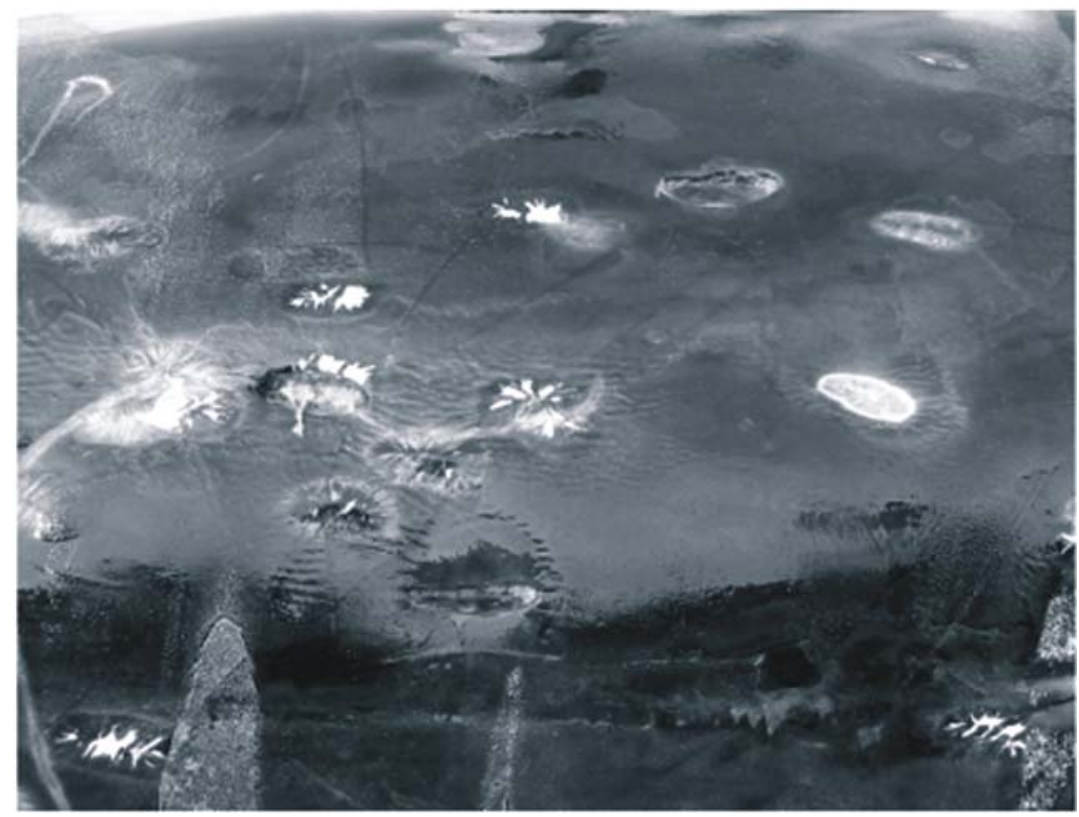

Figure 5. Scars and lesions on the M. mirus flank

\footnotetext{
${ }^{5}$ Dr. Luís C. Muniz-Pereira, IOC/FIOCRUZ. Rua Leopoldo Bulhões, 1480-térreo, Manguinhos, Rio de Janeiro, RJ $21041-210$ Brazil.
} 
Table 2. Cranial measurements of a Mesoplodon mirus specimen, stranded in São Sebastião, São Paulo, Brazil in May 2004.

\begin{tabular}{|c|c|c|}
\hline CRANIAL MEASUREMENTS DESCRIPTION & $\overline{\mathrm{cm}}$ & \% \%CBL \\
\hline 1. Condylobasal length & 75 & 100.0 \\
\hline 2. Length of rostrum & 41.8 & 55.7 \\
\hline 3. Tip of rostrum to posterior marginof pterygoid near midline & 58.2 & 77.6 \\
\hline 4. Tip of rostrum to most posterior extension of wing of pterygoid & 60.5 & 80.7 \\
\hline 5. Tip of rostrum to most anterior extension of pterygoid & 38.4 & 51.2 \\
\hline 6. Tip of rostrum to most posterior extension of maxillaries & 68.4 & 91.2 \\
\hline 7. Tip of rostrum to most posterior extension of maxillary plate & --- & -- \\
\hline 8. Tip of rostrum to anterior margin of superior nares & 52.7 & 70.3 \\
\hline 9. Tip of rostrum to most anterior point on the premaxillary crest & 56.0 & 74.7 \\
\hline 10. Tip of rostrum to most posterior extension of temporal fossa & 71.8 & 95.7 \\
\hline 11. Tip of rostrum to most posterior extension of lateral tip of premaxillary crest & $\begin{array}{l}\mathrm{L}=58.9 \\
\mathrm{R}=60.0\end{array}$ & $\begin{array}{c}78.5 \\
80\end{array}$ \\
\hline 12. Tip of rostrum to most anterior extension extension of pterygoid sinus & 46.1 & 61.5 \\
\hline 13. Length of temporal fossa & 14.2 & 18.9 \\
\hline 14. Length of orbit & 11.0 & 14.7 \\
\hline 15. Length of right nasal on vertex of skull & 6.3 & 8.4 \\
\hline 16. Length of nasal suture & 6.1 & 8.1 \\
\hline 17. Breadth of skull across postorbital process of frontals & 37.8 & 50.4 \\
\hline 18. Breadth of skull across zygomatic processes of squamosals & 36.4 & 48.5 \\
\hline 19. Breadth of skull across centres of orbits & 35.3 & 47.1 \\
\hline 20. Least breadth of skull across posterior margins of temporal fossae & 20.4 & 27.2 \\
\hline 21. Greatest span of occipital condyles & 10.9 & 14.5 \\
\hline 22. Greatest width of an occipital condyle & 4.0 & 5.3 \\
\hline 23. Greatest length of an occipital condyle & 8.1 & 10.8 \\
\hline 24. Greatest breadth of foramen magnum & 3.8 & 5.1 \\
\hline 25. Breadth of skull across exoccipitals & 30.2 & 40.3 \\
\hline 26. Breadth of nasals on vertex & 3.9 & 5.2 \\
\hline 27. Least distancebetween premaxillary crests & 1.8 & 2.4 \\
\hline 28. Greatest span of premaxillary crests & 15.7 & 20.9 \\
\hline 29. Least width of premaxillae where they narrow opposite superior nares & 3.7 & 4.9 \\
\hline 30. Greatest width of premaxillae anterior to place of measurement \# 29 & $\begin{array}{l}\mathrm{L}=5.2 \\
\mathrm{R}=6.1\end{array}$ & $\begin{array}{l}6.9 \\
8.1\end{array}$ \\
\hline 31. Width of premaxillae at midlength of rostrum & 1.8 & 2.4 \\
\hline 32. Width of rostrum in apices of antorbital notches & 17.1 & 22.8 \\
\hline 33. Greatest width of rostrum at midlength of rostrum & 7.4 & 9.8 \\
\hline 34. Greatest depth of rostrum at midlength of rostrum & 4.9 & 6.5 \\
\hline 35. Greatest transverse width of superior nares & 5.0 & 6.7 \\
\hline 36. Greatest inside width of inferior nares on the pterygoids & 10.4 & 13.9 \\
\hline 37. Height of skull & 26.9 & 35.9 \\
\hline 38. Greates width of temporal fossa & 8.2 & 10.9 \\
\hline 39. Least distance between maxillary foramina & 8.5 & 11.3 \\
\hline 40. Least distance between premaxillary foramina & 4.3 & 5.7 \\
\hline $\begin{array}{l}\text { 41. Distance from posterior margin of left maxillary foramen to most anterior } \\
\text { extension of left maxillary prominence }\end{array}$ & 6.6 & 8.8 \\
\hline 42. Greatest length of vomer visible at surface of palate & 13.6 & 18.1 \\
\hline 43. Length of tympanic bulla, left & 4.2 & 5.6 \\
\hline 44. Length of tympanic bulla, right & 4.4 & 5.8 \\
\hline
\end{tabular}


Table 3. Mandibular measurements of a Mesoplodon mirus specimen, stranded in São Sebastião, São Paulo, Brazil in May 2004.

\begin{tabular}{llcc}
\hline \hline MANDIBULAR MEASUREMENTS DESCRIPTION & $\mathrm{cm}$ & \% CBL \\
\hline \hline 1. & Length of mandible & 63.1 & 84.1 \\
2. & Greatest length of symphysis & 13.5 & 18 \\
3. & Height of mandible at coronoid process & 11.3 & 15.1 \\
4. & Outer height of mandible at midlength of alveolus & --- & --- \\
5. & Inner height of mandible at midlength of alveolus & -- & --- \\
6. & Length from most posterior extension of symphysis to most posterior of condyle & 48.9 & 65.2 \\
7. & Length from posteriormargin of alveolus to condyle & --- & --- \\
8. & Length of alveolus & --- & --- \\
9. & Width of alveolus & --- & -- \\
\hline \hline
\end{tabular}

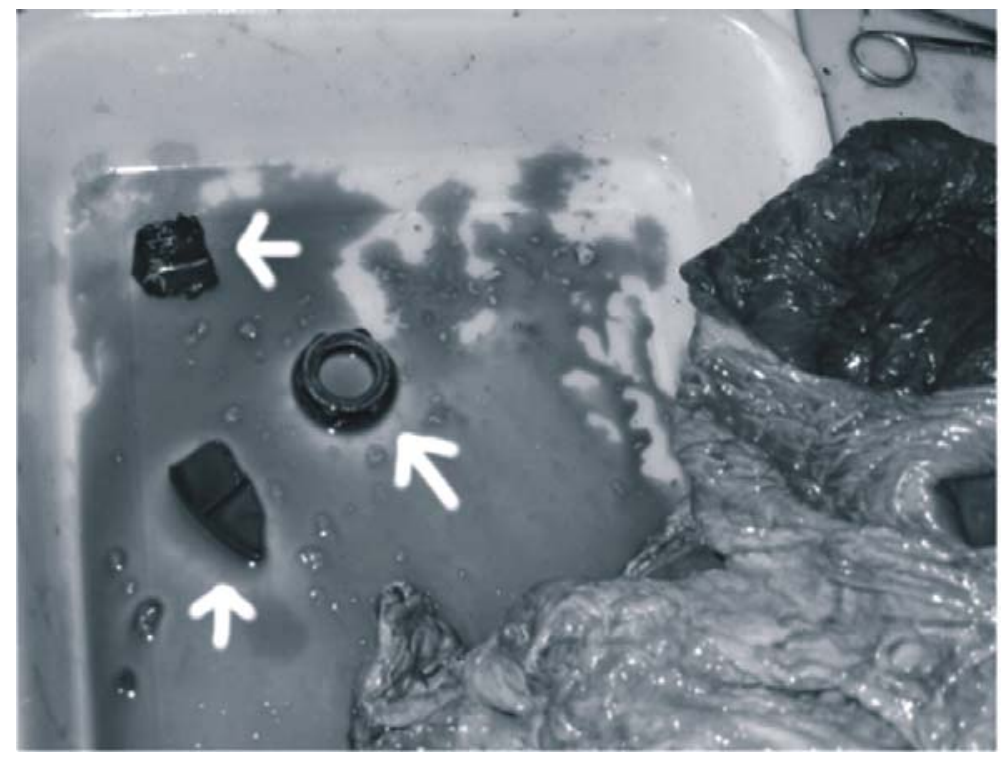

Figure 6. Plastic debris found in the M. mirus stomach

The only organ which could be measured and weighed was the left testis, measuring $23 \mathrm{~cm}$ in length and weighing $124.9 \mathrm{~g}$. Considering the turgid aspect of the testes, the physical maturity of the skeleton, and the whale's total length - very close to the maximum length for the species- this specimen could be close to or fully sexually mature. According to Mead (1989) the mean weight of the gonads of sexually mature males of Mesoplodon is $140-250 \mathrm{~g}$. These values are close to that obtained for the current specimen's testis.

Externally, the heart was $40 \mathrm{~cm}$ wide and $32 \mathrm{~cm}$ in height, and showed features similar to those found in other mammal hearts: four cavities (two atria and two ventricles). Detailed analysis of its anatomy is being carried out to describe its internal features.

Despite the blood sample becoming hemolyzed, analysis revealed a high level of hemoglobin $(30.3 \mathrm{~g} / \mathrm{dL})$, which could be a characteristic of deepdiving species. Two other species with characteristic offshore distribution, Delphinus delphis and Lagenorhynchus obliquidens, show lower hemoglobin values of 16.1-19.4 and 17-20g/dL, respectively (Bossart et al., 2001). High values of leukocytes $(94,200$ cells $/ \mathrm{mm}^{3}$ ) were also found and the presence of numerous bacteria (cocos) could suggest septicemia. Cultures of the swabs collected from the mouth, blowhole, Isistius bites, anal and genital splits, confirmed the presence of Vibrio vulnificus, $V$. parahemolyticus, V. alginolyticus, V. fluvialis, Vibrio sp., Aeromonas sobria and A. veronii. Swab cultures from this specimen were negative for Salmonella. Other studies on stranded cetaceans in Brazil have shown the presence of Vibrio vulnificus and V. fluvialis in Sotalia fluviatilis, Aeromonas veronii and Vibrio fluvialis in

\footnotetext{
${ }^{6}$ Dr. Dália dos Prazeres Rodrigues, / Laboratório de Enterobactérias/IOC/FIOCRUZ, Rua Leopoldo Bulhões, 1480-térreo, Manguinhos, Rio de Janeiro, RJ, 21041-210, Brazil.
} 
Eubalaena australis and Vibrio alginolyticus and Aeromonas sobria in Pontoporia blainvillei (S.Siciliano and D.P.Rodrigues, unpublished data, 2005).

A few epizoites identified as Penella balaenoptera were found fixed to the whale's left flank, confirming $M$. mirus as a host for this copepod (Mead, 1989).

The record of this specimen provides important information about external morphology, osteology, anatomy and natural history for this relatively poorly known species. Additionally, it confirms the presence of M. mirus in the Western Atlantic south of the Equator, just midway among other confirmed stranding areas: North Atlantic, southeastern Africa and southern Australia. Until now, the presence of $M$. mirus in the Southern Hemisphere had been confirmed only for warm-temperate waters of the Indian and South Pacific Oceans (Mead, 1989). MacLeod (2000) mentioned that these few occurrences could be from a population separated from that of the Northern Hemisphere, suggesting an anti-tropical distribution for this species. The coloration of this individual from Brazil (SOSMM 130) is consistent with such an antitropical distribution, being more similar to other Southern Hemisphere individuals than to ones from the North Atlantic, despite the closer proximity between southern Brazil and the southern-most tip of the range of $M$. mirus in the Northwestern Atlantic (MacLeod, 2000). Therefore, this specimen suggests that in the Southern Hemisphere, M. mirus probably has a wider distribution than previously thought, but that animals in the North Atlantic and Southern Hemisphere form different breeding populations even within the Atlantic, with different distinct colorations.

The present record adds a new beaked whale species for the western South Atlantic as well as for South America and increases to 44 the number of cetaceans recorded for the Brazilian coast.

\section{Acknowledgements}

We thank Projeto SOS Mamíferos Marinhos team for helping during necropsy, particularly Fernanda de N. Caso, Márcio T. Silva, Monique Winck and Rafael N. Abib. MSc. Juliana Marigo and Daphne Wrobel provided useful literature and Manoel Trindade for taking the photo shown in this article. Dr. Sheila M. F. Mendonça de Souza (FIOCRUZ/ENSP/Departamento de Endemias, Laboratório de Paleopatologia) kindly examined x-rays from the mandible and commented on the tooth positions. Dr. Luís C. Muniz-Pereira (Instituto Oswaldo Cruz/ FIOCRUZ, Departamento de Helmintologia) identified the parasites found in the stomach, Dr. Tagea K. S. Björnberg (CEBIMar - USP) identified the epizoites. Dr. Dália dos Prazeres Rodrigues and Dr. Marise D. Asensi (Instituto Oswaldo Cruz/FIOCRUZ, Departamento de Bacteriologia, Laboratório de Enterobactérias) analyzed the collected swabs. Dr. Colin MacLeod confirmed the species identification and, together with Dr. Alan Baker, one anonymous referee and the editors, provided useful comments to the manuscript.

\section{References}

BAKER, A.N. (1983) Whales E dolphins of New Zealand and Australia - an identification guide. Victoria University Press, New Zealand, 135p.

Bossart, G.D.; Reidarson, T.H.; Dierauf, L.A. and Duffield, D.A. (2001) Clinical Pathology. Pages 383-436 in Dierauf, L.A. AND Gulland, F.M.D. (Eds) Handbook of Marine Mammal Medicine 2nd ed. CRC Press, Boca Raton, FL, USA.

Dalebout, M.L., Van Helden, A., Van Waerebeek, K. And Baker, C.S. (1998) Molecular genetic identification of southern hemisphere beaked whales (Cetacea: Ziphiidae). Molecular Ecology 7: 687-694.

MacLeOD, C.D. (2000) Review of the distribution of Mesoplodon species (order Cetacea, family Ziphiidae) in the North Atlantic. Mammal Review 30: 1-8.

Maia-Nogrueira, R. And Nunes, J.A.C.C. (2005) A possible record of the Layard's beaked whale, Mesoplodon cf. layardii (Gray, 1856) in northeastern Brazil. The Latin American Journal of Aquatic Mammals 4(2): 137-139.

Martins, A.M.A., Alves Jr., T.T., Furtado Neto, M.A.A. And LiEN, J. (2004) The most northern record of Gervais' beaked whale, Mesoplodon europaeus (Gervais, 1855) for the Southern Hemisphere. The Latin American Journal of Aquatic Mammals 3: 151-156.

MeAD, J.G. (1989) Beaked whales of the Genus Mesoplodon. Pages 349-430 in Ridgway, S.H. AND HarRISON, R. (Eds) Handbook of Marine Mammals, vol. 4. River Dolphins and the Larger Toothed Whales. Academic Press, San Diego, CA, USA.

Moore, J.C. (1963) Recognizing certain species of beaked whales of the Pacific Ocean. American Midland Naturalist 70: $396-428$.

NoRRIS, K.S. (1961) Standardized methods for measuring and recording data on the smaller cetaceans. Journal of Mammalogy 42: 471-476.

Perrin, W.F. (1975) Variation of spotted and spinner porpoises (genus Stenella) in the eastern Pacific and Hawaii. Bulletin of the Scripps Institute of Oceanography 21: 1-206.

Pinedo, M.C., Lammardo, M.P. and Barreto, A.S. (2001) Review of Ziphius cavirostris, Mesoplodon grayi and Lagenodelphis hosei (CETACEA: ZIPHIIDAE and DELPHINIDAE) in Brazilian waters, with new records from southern Brazil. Atlântica 23: 67-76.

Ross, G.J.B. (1984) The smaller cetaceans of the south east coast of southern Africa. Annals of the Cape Province Museum (Natural History) 15: 173-410.

Santos, M.B., Pierce, G.J., Herman, J., López, A.,Guerra, A., Mente, E. And Clarke, M.R. (2001) Feeding ecology of Cuvier's beaked whale (Ziphius cavirostris): a review with new information on the diet of this species. Journal of the Marine Biological Association of the United Kingdom 81: 687-694.

Santos, M.C. De O., Zampirolli, E., Castro, A.F.V. De And Alvarenga, F.S. (2003) A Gervais' beaked whale (Mesoplodon europaeus) washed ashore in southeastern Brazil: extra limital record? Aquatic Mammals 29: 404-410. 
Secchi, E.R. And Zarzur, S. (1999) Plastic debris ingested by a Blainville's beaked whale, Mesoplodon densirostris, washed ashore in Brazil. Aquatic Mammals 25: 21-24.

Siciliano, S. (1994) Review of small cetaceans and fishery interactions in coastal waters of Brazil. Pages 241-250 in
Perrin, W.F., Donovan, G.P., Barlow, J. (Eds) Gillnets and cetaceans. Reports of the International Whaling Commission, Special Issue 15.

ZERBINI, A.N. AND SECCHI, E.R. (2001) Occurrence of Hector's beaked whale, Mesoplodon hectori, in Southern Brazil. Aquatic Mammals 27: 149-153. 